Бычкова Гульфира Мубараковна, к.э.н., доцент, Ангарский государственный технический университет, e-mail: gulfira_agta@mail.ru КООРДИНАЦИЯ ЦЕЛЕЙ И ЗАДАЧ ЛОГИСТИКИ И УПРАВЛЕНИЯ КАЧЕСТВОМ Bychkova G.M.

\title{
COORDINATION OF OBJECTIVES AND TASKS OF LOGISTICS AND QUALITY MANAGEMENT
}

\begin{abstract}
Аннотация. Исследованы тенденции развития целей и задач логистики и управления качеством. Обоснована необходимость и предложен инструмент координации целей и задач логистики и управления качеством.

Ключевые слова: цели логистики, цели управления качеством, инструмент координации.

Abstract. Trends in the development of the goals and objectives of logistics and quality management are investigated. The tool for the coordination of the objectives and tasks of the logistics and quality management is suggested.
\end{abstract}

Keywords: goals logistics, objectives quality management, coordination tool.

В современных условиях, когда большая часть предприятий уже завоевала определенные доли рынка или виды экономической деятельности, они заинтересованы в стабилизации своего рыночного положения с сохранением резерва для роста. Здесь на первое место выходит проблема создания конкурентного преимущества как результата осуществления совокупности видов внутрихозяйственной деятельности предприятия - инновационной, производственной, финансовой, инвестиционной, маркетинговой, управления персоналом, логистики. По нашему мнению, объединяющим стержнем для всех видов деятельности, может стать управление качеством, поскольку:

- на современном уровне развития понятие «качество» рассматривается как комплексная составляющая, включающая в себя качество: конечного продукта, управления, поставки или работ, жизнедеятельности людей (сотрудников) и общества в целом;

- цель управления качеством - поддержание уровня и состояния качества продукции в соответствии с экономическими интересами производителя и потребителя, безопасности и экологичности продукции;

- управление организацией, применительно к качеству, означает, что вся деятельность подчиняется установленным целям по качеству [2].

Значительные резервы для улучшения экономических показателей деятельности предприятий имеет оптимизация материальных потоков (МП), поскольку доля расходов на логистику остается высокой (в стоимости продукта, попадающего к потребителю, около 70\% составляют расходы на логистику) [1].

Управление организацией, применительно к качеству, предполагает координацию целей, функций и задач логистики и управления качеством, а опти- 
мизация материальных потоков должна рассматриваться как одна из составляющих системы управления качеством.

Цель и задачи логистики в организации нельзя рассматривать отдельно от стратегических целей бизнеса. Она состоит в рациональной координации физического распределения, эффективном управлении материальными и сопровождающими потоками, экономии расходов, повышении уровня обслуживания, достижении стратегических целей и конкурентных преимуществ [3].

В качестве инструмента координации целей и задач логистики и управления качеством предлагается их ранжирование:

1. Основные функции предприятия, определяющие качество бизнеса (стратегическое и оперативное управление, маркетинг, проектирование продукции и (или) бизнес-процессов, материально-техническое обеспечение бизнеспроцессов, управление технологией осуществления процессов, подготовка кадров, руководство трудовыми ресурсами, поставка продукции, техническое обслуживание и ремонт).

2. Процессы, осуществление которых обеспечивается системой качества предприятия (определение ответственности руководства, управление ресурсами, управление процессами по стадиям жизненного цикла продукции (услуг), измерение и анализ деятельности, анализ поставщиков, анализ и учет требований потребителей).

3. Выявление основных источников экономического эффеекта от использования логистики (снижение запасов на пути движения материального потока, снижение транспортных расходов, сокращение затрат ручного труда и соответствующих расходов на операции с грузом).

Такой подход позволит системно формировать основные цели и задачи управления качеством с учетом стратегии бизнеса, а цели и задачи логистики будут корректироваться в рамках возможностей системы качества организации.

\section{ЛИТЕРАТУРА}

1. Анисимов В.С. Логистика / В.С. Анисимов. М.: Юнити, 2014. 653 с.

2. Тебекин А.В. Управление качеством / А.В. Тебекин, П.А. Тебекин. М.: ЮРАЙТ, 2012. 222 с.

3. Щербаков В.В. Логистика в свете современных тенденций развития бизнеса / В.В. Щербаков // Коммерция и логистика: Сборник научных трудов. Вып. 7 СПб.: Изд-во СПбГУЭФ, 2010. 